\title{
A New Pharmacokinetic Model Describing the Biodistribution of Intravenously and Intratumorally Administered Superparamagnetic Iron Oxide Nanoparticles (SPIONs) in a GL26 I Xenograft Glioblastoma Model [Corrigendum]
}

Klapproth AP, Shevtsov M, Stangl S, Li WB, Multhoff
G. Int J Nanomedicine. 2020;15:4677-4689.

The authors have advised the author and affiliation list on page 4677 is incorrect. The correct author list and affiliations are as follows.

\author{
Alexander P Klapproth ${ }^{1,2, *}$ \\ Maxim Shevtsov ${ }^{1,3-7, *}$ \\ Thomas J Carter ${ }^{8}$ \\ Stefan Stangl' \\ Kerry Chester ${ }^{8}$ \\ Wei Bo $\mathrm{Li}^{2}$ \\ Gabriele Multhoff'
}

'Center for Translational Cancer Research Technische Universität München (TranslaTUM), Klinikum Rechts Der Isar, Munich, Germany; ${ }^{2}$ Institute of Radiation Medicine, Helmholtz Zentrum München, German Research Center for Environmental Health $(\mathrm{GmbH})$, Munich, Germany; ${ }^{3}$ Institute of Cytology of the Russian Academy of Sciences (RAS), St. Petersburg, Russia; ${ }^{4}$ Department of Biotechnology, First Pavlov State Medical University of St. Petersburg, St. Petersburg, Russia; ${ }^{5}$ Almazov National Medical Research Centre, Russian Polenov Neurosurgical Institute, St. Petersburg, Russia; ${ }^{6}$ National Center for Neurosurgery, Nur-Sultan, Kazakhstan; ${ }^{7}$ Department of Biomedical Cell Technologies, Far Eastern Federal University, Vladivostok, Russia; ${ }^{8} \mathrm{UCL}$ Cancer Institute, University College London, London, UK

*These authors contributed equally to this work
Page 4682, Intravenously Injected SPIONs section, the text "To further validate the model, two datasets from mice with intravenously injected SPIONs were analyzed" should read "To further validate the model, two previously published supplementary datasets from mice with intravenously injected SPIONs were analyzed".

The authors apologize for these errors.

\section{Publish your work in this journal}

The International Journal of Nanomedicine is an international, peerreviewed journal focusing on the application of nanotechnology in diagnostics, therapeutics, and drug delivery systems throughout the biomedical field. This journal is indexed on PubMed Central, MedLine, CAS, SciSearch ${ }^{\mathbb{R}}$, Current Contents ${ }^{\mathbb{B}} /$ Clinical Medicine,

Journal Citation Reports/Science Edition, EMBase, Scopus and the Elsevier Bibliographic databases. The manuscript management system is completely online and includes a very quick and fair peer-review system, which is all easy to use. Visit http://www.dovepress.com/ testimonials.php to read real quotes from published authors. 